\title{
Reflection of the mid-Ludfordian Lau Event in conodont faunas of Bohemia
}

\author{
LADISLAV SLAVÍK, JIŘí KŘíž \& PETER CARLS
}

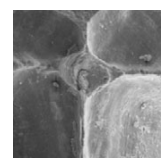

\begin{abstract}
Conodont faunas of the Polygnathoides siluricus Zone (Ludfordian, Ludlow) from shallow-water environments of Bohemia are characterized by relatively high taxonomic diversity that reflects an interval with taxa thriving due to increased nutrient supply in rather stable environments during the pre-Lau Event time, as has been documented globally. Although the conodont faunas in strata with $P$. siluricus are more diversified and variable than those in the interval instantly following, the uninterrupted ranges of several taxa (of genera Wurmiella, Ozarkodina and Delotaxis) show that the change in conodont faunas in the sections is not as drastic in Bohemia as described on Gotland and that the extinction rate was rather moderate. A detailed correlation of conodont distribution in the sections indicates, however, that a large part of the Lau Event is not preserved in the shallow water environment of the former Reporyje Volcanic Elevation. Accordingly, timing and spatial image of the conodont extinction are thus partly obscured. Only a short interval with considerably diminished conodont elements during the lower range of Ozarkodina? snajdri with random occurrences of Pedavis latialatus, corresponds to the part of the "Icriodontid Zone" on Gotland, i.e. the uppermost part of the Lau Event. This incompleteness in record confirms sedimentary starvation in the shallow environment on the former volcanic elevation in this part of the Prague Basin. $\bullet$ Key words: Silurian, Lau Event, conodonts, Prague Basin, Gotland, correlation.
\end{abstract}

SLAVÍK, L., KŘíž, J. \& CARLS, P. 2010. Reflection of the mid-Ludfordian Lau Event in conodont faunas of Bohemia. Bulletin of Geosciences 85(3), 395-414 (6 figures). Czech Geological Survey, Prague. ISSN 1214-1119. Manuscript received June 10, 2010; accepted in revised form August 23, 2010; published online September 9, 2010; issued September 30, 2010.

Ladislav Slavík (corresponding author), Institute of Geology AS CR, v.v.i., Rozvojová 269, CZ-16500 Praha 6, Czech Republic; slavik@gli.cas.cz•Jiři Křǐz, Czech Geological Survey, Klárov 3, P.O. Box 85, CZ-118 21, Praha 1, Czech Republic; jiri.kriz@geology.cz•Peter Carls, Institute of Environmental Geology, Braunschweig University of Technology, Pockelsstrasse 3, D-38023 Braunschweig, Germany

Since the introduction of the mid-Ludfordian Lau Event (Jeppsson 1998), an increasing number of studies have appeared that deal with this prominent Event in various parts of the world. The most recent summary of related papers was provided by Barrick et al. (2010). The Event has been partly recorded also in the Prague Basin (Barrandian area) by Lehnert et al. (2003) and Lehnert et al. (2007a) using the $\delta^{13} \mathrm{C}$ record. The Lau Event was characterized originally by a change in conodont faunas, partially during and after the Polygnathoides siluricus range on Gotland, Sweden. Accordingly, information about local conodont faunas is essential for direct documentation and evaluation of the Event in other regions. The record of conodont taxa and the succession of their disappearance or re-appearance usually provide an important tool for precise orientation in relative time. However, in many areas, where the Lau Event has been reported, detailed conodont data are missing. In part, this was also the case of the Prague Basin, although other biostratigraphic indices, e.g., graptolites and macrofauna are available (e.g., Kříž 1992). With regard to conodonts, with exception of the first and the last appearance datum of few index taxa, more complex information across the Lau Event in the Prague Basin was missing; this was also remarked by Barrick et al. (2010) in their evaluation of global data around the Lau Event.

The aim of the present paper is to fill in the gap in information by providing of new conodont data from the mid-Ludfordian interval from Bohemia and their correlation with available data from previous studies. For the new sampling, the Požáry section was chosen because it seems to be the most suitable section with respect to conodonts in the shallow environment in the region. Moreover, detailed information about conodonts from the lower part of the interval is needed. This paper also represents a part of a long-term study that is focused on the late Silurian conodont stratigraphy in the Barrandian within the project "Late Silurian integrated stratigraphy". 
Besides graptolites, conodont faunas are considered to be one of the most precise stratigraphic tools in the Silurian. In spite of recently refined conodont zonal scales for the late Silurian in several regions of the world, there still remain deficiencies with regard to global correlation (e.g., problematic zonation of the Přídolí as discussed in Carls et al. 2007). Conodont stratigraphy, if correctly applied by accurate correlation of conodont time-markers and other guide taxa, also helps with precise dating of other regional and/or global Silurian events. However, for the successful and unbiased correlation, there exists an essential condition: a necessity of good documentation of faunas. This concerns especially the fact that taxonomy of many stratigraphically important conodonts has been changed several times during last decades and thus some taxonomic names that appear in literature without available figures or comments may often cause difficulties for correlation. Since the pioneer work by Walliser (1964) who provided the first conodont biostratigraphic framework for the Silurian, the late Silurian zonation was subsequently refined or modified by many authors. Successful local conodont zonations have been established in Sardinia (Corradini \& Serpagli 1999), Gotland, Sweden (Jeppsson et al. 2006) or Australia (Jeppsson et al. 2007). The fundamental zonal framework that was coined by Walliser (1964) with respect to the Ludfordian part - a stratigraphic interval concerned in this paper, remain practically unchanged; the zones ploeckensis, siluricus, snajdri/latialatus and crispa are still universally in use in contrast to the unsatisfactory situation in the Prrídolí (see comments in the next chapter).

\section{Conodonts of the Ludfordian from the Prague Basin}

Conodont studies in the late Silurian of the Prague Basin dates back from the above mentioned work by Walliser, who also included conodont data from this area into his Silurian zonation. Most of the late Silurian conodont works in the stratotype area were focused on the Ludlow/Přídolí boundary and Přídolí Series. An enormous conodont work has been done by H.P. Schönlaub (in Chlupáč et al. 1980 and in Kř́ž et al. 1986) who made a large summary of conodont faunas obtained from numerous sections and localities that were sampled and studied by him or by previous authors. Detailed sampling and revised data from previous studies enabled recognition of Walliser's zones - ploeckensis, siluricus, latialata, snajdri, crispa and eosteinhornensis. Carls et al. (2007) provided a critical revision of conodont stratigraphy across the Silurian-Devonian boundary, using data from the Požáry section.

In regard to Ludfordian conodonts which are the main subject of this study, only few specimens (in papers by Walliser 1964, Chlupáč et al. 1980 and Carls et al. 2005) have been figured so far from the interval. The latter authors described a taxon with incipient alternating denticulation in the spathognathodontid clade from the Ludlow in the Požáry section. This morphological progress represents a significant step in the evolution of Spathognathodontidae and offers also a biostratigraphical potential. However, the lack of figures and characteristics of specimens obtained from the Ludfordian of Bohemia is nowadays a disadvantage for correlation, because the taxonomical concepts of many species of the early workers cannot be ascertained from faunal lists and many stratigraphically important subspecies and morphotypes were subsequently introduced, or other taxa were synonymized (cf. Murphy et al. 2004). Deficiency of well-documented conodont faunas could also negatively bias precision of stratigraphic correlation of global events. This concerns also the Lau Event reported from the Prague Basin (Lehnert et al. 2007a) versus the Kozlowskii Event (Štorch 1995a, b; Manda \& Kř́ž 2006). Therefore, biostratigraphical knowledge of the late Silurian in Bohemia must be enhanced by new data; this paper represents a partial contribution to the issue.

\section{The Lau Event}

Marked changes in several faunal groups in the stratigraphic interval corresponding approximately to siluricus and immediate post-siluricus time have been recognized in many areas of the world. As noted by Manda \& Kř́ž (2006), in the Prague Basin, the significant change was recognized already by Jahn (1902) between the trilobite horizons of Cromus beaumonti and Ananaspis fecunda. This significant change also corresponds to the prominent Ludfordian change in facies and faunas described by Kříž (1991) before the end of the range of the graptolite Neocucullograptus kozlowskii and still within the Pseudomonoclimacis latilobus graptolite Zone. The graptolite extinction has been described by Urbanek (1993) and Koren (1993) as Podoliensis extinction Event, later the term Kozlowskii Event was widely accepted (Štorch 1995a, b; Melchin et al. 1998). Also other faunal changes and events were described around the world in the corresponding stratigraphic span, e.g., the Pentamerid Event of Talent et al. (1993)

Figure 1. A-C - Location of the Požáry Quarries within the Barrandian Paleozoic, in the vicinity of Praha- ̌eporyje. • D - sampled interval at the locality. $\bullet$ E - marking of the range of Polygnathoides siluricus at the section. $\bullet$ F - detail of the section with marked position of some numbered beds (after Kř́̌ 1965, unpublished part of the Požáry section). 
Ladislav Slavík et al. • Reflection of the mid-Ludfordian Lau Event in conodont faunas of Bohemia

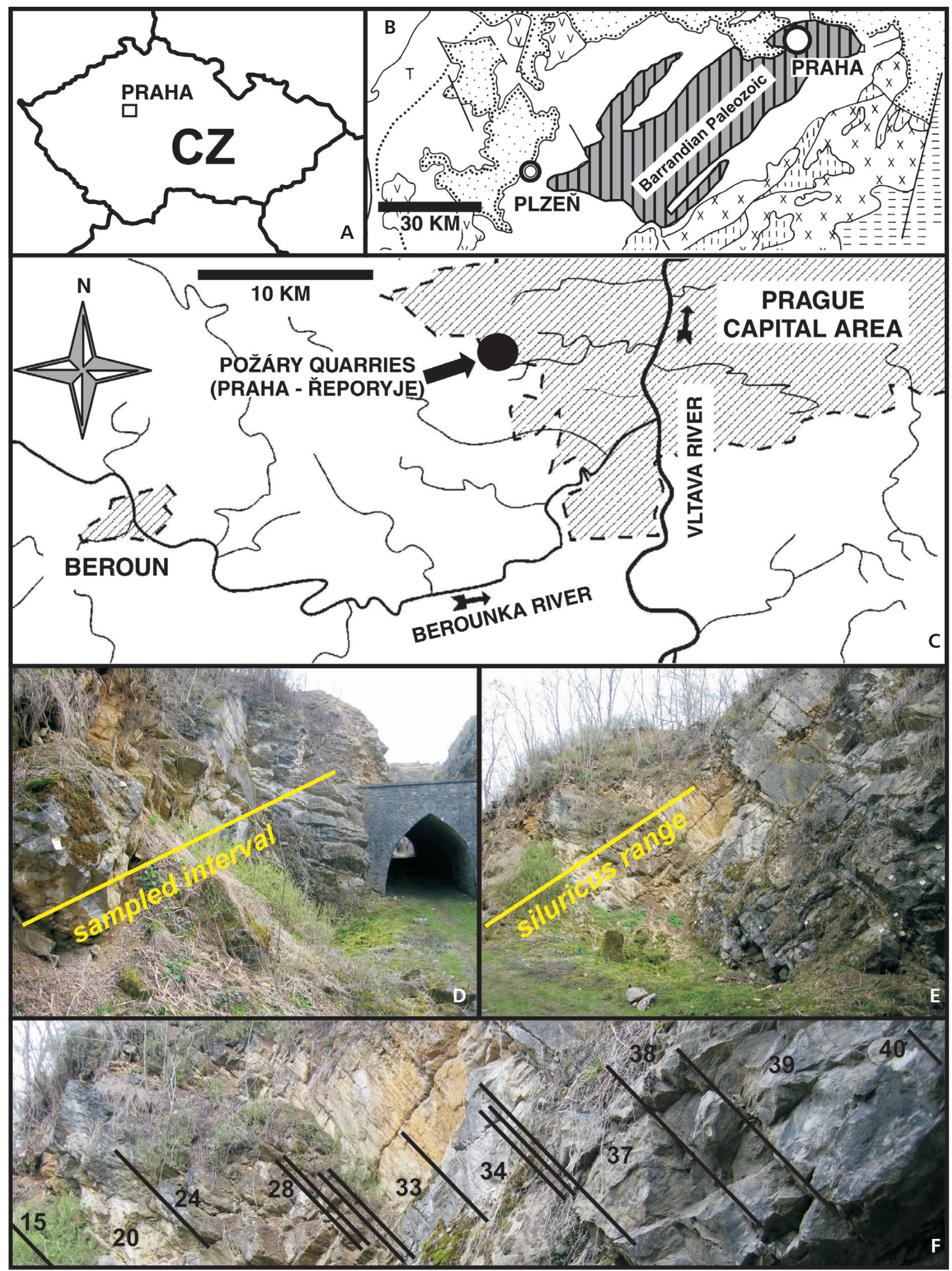


reflecting change in brachiopod faunas. A strong decrease in diversity of conodonts between the faunas with Polygnathoides siluricus and succeeding faunas was first observed in New South Wales (Australia) by Link \& Druce (1972) and then recognized in other areas (e.g., Sardinia, Corradini et al. 2009). For a similar decrease in conodont diversity observed on Gotland (Sweden), Jeppsson (1998) introduced the name "Lau Event", a term that has since become widely in use. The event is accompanied by the strongest positive $\delta^{13} \mathrm{C}$ isotope excursion in the entire Palaeozoic (cf. Munnecke et al. 2003) and is correlated in many parts of the World, mostly just on the basis of this carbon isotope excursion (CIE); for summary see Barrick et al. (2010). The causes of the Event were probably very complex and an explanation of the CIE that roughly accompanies the event, is still subject to discussion; several different and competing interpretations can be found in literature (e.g., Jeppsson 1990, Wenzel \& Joachimski 1996, Johnson 2006, Lehnert et al. 2007b). Regardless of various names used by different authors for the global faunal turnovers of varying intensity that approximately stratigraphically coincide and are partly associated with CIE, the name "Lau Event" is herein regarded just in terms concerning strictly conodont faunas, as it was proposed originally.

The time of the conodont Lau Event is regarded by some authors as one of the most conspicuous oceanic events (see review by Calner 2008). The event proper was originally postulated, because several conodont taxa disappeared in a stepwise extinction that started before the last appearance datum (LAD) of the conodont taxon Polygnathoides siluricus Branson \& Mehl, 1933 in the upper part of the Hemse beds on Gotland. The stratigraphic ranges of taxa known on Gotland from the interval late Llandovery-early Přídolí were shown by Jeppsson (1984, text-fig. 3). Jeppsson \& Aldridge (2000) provided a sequence of disappearing and appearing conodont taxa around the proposed Event with positions in meters in the Botvide 1 locality. They stated that by the end of the Event, 13 out of 18 taxa from Gotland disappeared. The list of fauna includes, however, also some endemic species and simple cone elements which are not relevant to the problem because of their limited distribution.

The conodont extinction related to the Event on Gotland was reported as stepwise and very severe process. To describe the Lau Event, Calner (2005) stated: "The event caused considerable extinctions and changes in community structures. Among conodonts, no plat- form-equipped taxon survived, and disaster conodont faunas dominated by a single taxon developed during the most severe part of the event." Herein is necessary to note that only conodonts with large platforms were considered as "platform-equipped taxa" because conodonts (e.g., " $O$. excavata" = Wurmiella excavata Branson \& Mehl and " $O z$. confluens" = Ozarkodina typica Branson \& Mehl) do occur across the upper part of the Hemse Group and Eke Fm. as shown by Jeppsson (1984, text-fig. 3) and Jeppsson \& Aldridge (2000, p. 1144). The conodont faunal change in strata above the range of $P$. siluricus is however significant, as it was shown in several areas around the globe, e.g. Nevada (Klapper \& Murphy 1974), Australia (Link \& Druce 1972, Jeppsson et al. 2007), Sardinia (Barca et al. 1995, Corradini et al. 2009) or most recently from other parts of North America - southern Laurentia (Barrick et al. 2010). Following the actual stratigraphic scale from Gotland provided by Jeppsson (2005, text-fig. 2) and Jeppsson et al. (2006, text-fig. 1), the Lau Event is shown to comprise a larger (upper) part of the P. siluricus Zone and the entire "Icriodontid Zone" (a local zone on Gotland) that precede the $O z$. snajdri Zone - the zone just above the Event.

Regardless of this, the degree of precision for correlation of the strata related to the Lau Event varies from region to region, although the Event has been approximated by carbon isotope records, which, however, are more or less intense. The relation between conodont and graptolite index taxa around the Lau Event remains unclear, however it is believed that the increase of $\delta^{13} \mathrm{C}$ starts within latest $N$. kozlowskii graptolite Zone; the entire long lasting excursion (CIE) is, however, poorly constrained by biozonation as Barrick et al. (2010) have summarized.

\section{Požáry Quarries - location, geological overview and previous work}

The Požáry Quarries is one of the most famous localities in the Prague Basin for biostratigraphic studies. The locality lies E of Reporyje village (Fig. 1C), that belongs to WSW margin of Prague capital territory (GPS location: $\left.50^{\circ} 01.720^{\prime} \mathrm{N} ; 14^{\circ} 19.449^{\prime} \mathrm{E}\right)$. The locality consists of several quarries, outcrops and connecting tunnels. The section above the entrance tunnel is the GSSP locality of the Př́idolí Series (described in detail by Kř́̌ž et al. 1986) and is known as the Požáry section. In literature the quarries are

Figure 2. Stratigraphic section with sampled interval comprising the siluricus Zone and lower part of the Lau Event equivalent in the Požáry Quarries. The figure shows distribution of the most important conodont taxa and numbers of elements (e.g., "8Pa" means $8 \mathrm{~Pa}$ elements in the sample, "11el" means 11 elements of different kinds belonging to the taxon in the sample). Element frequency in samples is based on the total number of conodont specimens and relative conodont diversity is based on quantity of determined taxa (rather exceptional - undetermined elements were not considered in the graph). The bed numbers are adopted from Kříž (1965, unpublished part of the Požáry section). 
Ladislav Slavík et al. • Reflection of the mid-Ludfordian Lau Event in conodont faunas of Bohemia

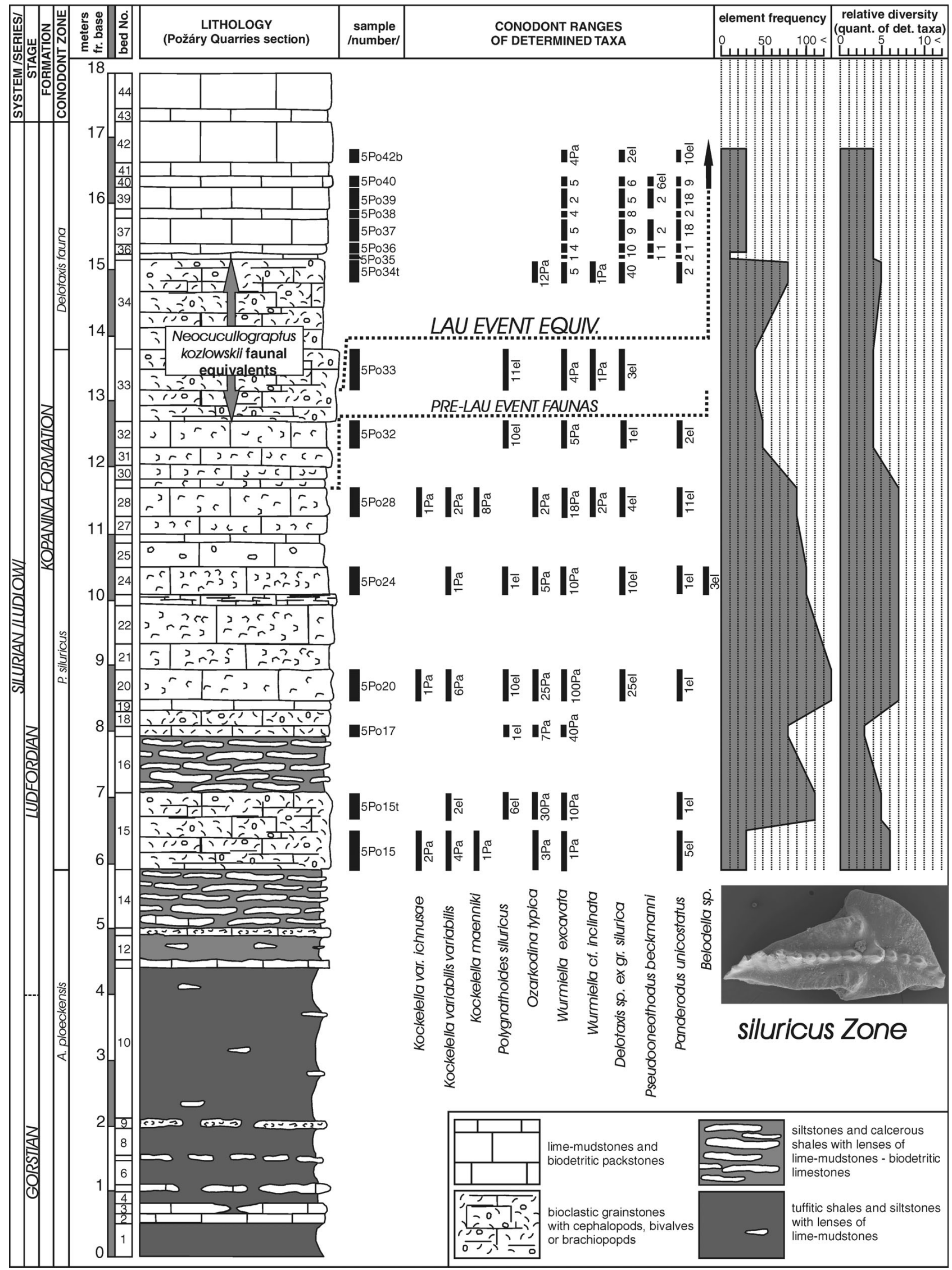


known as Požár 1, Požár 2 (e.g., Bouček 1937, Prokop 1951, Kříž et al. 1986, text-fig. 3; Kříž 1999). Few tens of meters E of Požár 1 and Požár 2 quarries lies an active unnamed quarry that arose by enlargement of former quarries (e.g., V rokli, Vokounka) and in literature is informally named as Požár 3 (Slavík 2004b; Koptíková et al. 2010a, b). The interval newly sampled is in the protected part of the locality, close to the entry of the entrance tunnel (see Fig. 1D-F).

Previous geological and paleontological studies of various stratigraphic intervals (Ludlow to Emsian) of the Požáry Quarries were undertaken by Bouček (1937), Chlupáč (1953, 1957), Chlupáč et al. (1972), Barnett (1972), Kř́̌ž et al. (1986), Vavrdová (1989), Manda (2003, 2008), Slavík (2004a, b), Manda \& Kř́iž (2006), Slavík et al. (2007), Carls et al. (2007), Lehnert et al. (2007a), Koptíková et al. (2010a, b), Slavík (in press) among others. The first detailed (bed-by-bed) study of the Ludlow-Přídolí interval was made by Kříž (1965, unpublished data). His study including detailed descriptions and numbering of beds was the basis for the GSSP definition (Kříž et al. 1981, 1986) and the lithological framework of the Ludlow interval in the Požáry section by Kř́ž is used in this paper (Fig. 2).

The Ludlow interval in the Požáry section (Fig. 2) starts in tuffitic shales and siltstones with lenses of calcareous mudstones. The sampled interval starts from bed No. 15 consisting of bioclastic packstones with common trilobites, cephalopods, bivalves and brachiopods; this is followed by succession of mostly cephalopod wackstones and packstones (for more detailed description see e.g., Kř́žz 1992, Lehnert et al. 2007a). A shallowing upward trend can be observed above the deeper-water tuffitic shales (beds Nos. 1 to 14) and composed of bioclastic packstones with numerous brachiopods and cephalopods (beds Nos. 15 to 18$)$.

Graded grainstones interpreted as tempestites (Lehnert et al. 2007a) are present from bed No. 18. Beds No. 33 and 34 are formed by massive grainstones and contain fauna coeval to the N. kozlowskii graptolite Zone and are followed by mostly crinoidal grainstones with the Ananaspis fecunda trilobite horizon. At the level of the bed No. 33 and above (up to bed No. 41) paleokarst indications were observed (Lehnert et al. 2007a); accordingly, extreme shallowing or even stratigraphic gaps of various scale are expected in this interval. As seen from the lithology (Fig. 2), the sampled part of the section reflects an intense fluctuation in depth that can be seen also in other Ludfordian sections in the Basin (see Manda \& Kříž 2006, text-fig. 2). The Požáry section and the nearby equivalent section at Mušlovka Quarry cover a part of the Reporyje Volcanic Elevation, which is the WNW part of the Ludfordian isolated carbonate platform in the eastern part of the Prague Basin, as interpreted Manda \& Kř́̌ž (2006).
Conodonts from different stratigraphical intervals of the Požáry Quarries were studied by Barnett (1972), Mehrtens \& Barnett (1976), Schönlaub (in Chlupáč et al. 1980 and in Kříž et al. 1986), Weddige (in Chlupáč et al. 1986), Slavík (2004a, 2004b), Slavík et al. (2007) and Carls et al. (2005, 2007). As mentioned above, the most important contribution to the conodont knowledge of the Ludlow and Ludlow-Př́ídolí boundary interval at the Požáry section was done by Schönlaub who studied conodonts also from the corresponding levels in several other sections (e.g., Marble Quarry, Mušlovka Quarry and Hvížd'alka). According to Schönlaub (in Kř́iž et al. 1986, p. 336), the conodont zonation in the Silurian part of the Požáry section starts with the A. ploeckensis Zone and is followed by a succession including $P$. siluricus, Oz.? snajdri, Ped. latialatus, Oz.? crispa zones in the Ludlow, and by a rather problematic "Oz. eosteinhornensis" Zone in the Přídolí. In large detail, the conodont data were provided from the interval between beds No. 86-106, i.e. the interval of the Ludlow-Přídolí boundary, on which their study was primarily focused. As the previous conodont work overview has shown, there is a dearth of knowledge concerning conodonts from the critical interval related to the Lau Event, i.e. from the lower part of the Požáry section.

\section{Material and methods}

Conodont samples were taken from the $10.8 \mathrm{~m}$ thick interval of Ludlow age (bed No. 15 to bed No. 42) of the predominantly carbonatic succession in the Požáry section that represents the time of $P$. siluricus plus a short post-siluricus time. Average weight of a sample varies from 3 to $5 \mathrm{~kg}$. The samples were taken mostly from the entire thickness of limestone bed or from a part of it as seen on Fig. 2 (collective samples). The rock was disintegrated into approximately $7 \mathrm{~cm}$ large pieces and processed using standard acidizing techniques with 10 to $15 \%$ acetic acid. Residues were washed through calibrated double sieves of $2.24 \mathrm{~mm}$ (upper) and $90 \mu \mathrm{m}$ (lower) meshes. Wet residues were washed with acetone and dried. Dried residues of up to $130 \mathrm{ml}$ were concentrated using heavy liquids (tribrommethane), because the grains of residues were not too porous for upgraded magnetic susceptibility treatment method by Carls \& Slavík (2005). Conodonts and other bioclasts were obtained from all samples. The total number of conodonts is more than 950 of complete or fragmented specimens. The conodont material was photographed directly in aluminium cells using a digital camera Leica D160 and a stereomicroscope Leica MZ7.5s in order to observe the distribution of white matter on elements before metal coating for SEM images. The SEM images of 96 selected conodont elements coated with gold were made by using Cameca SX100. The conodont material from this 


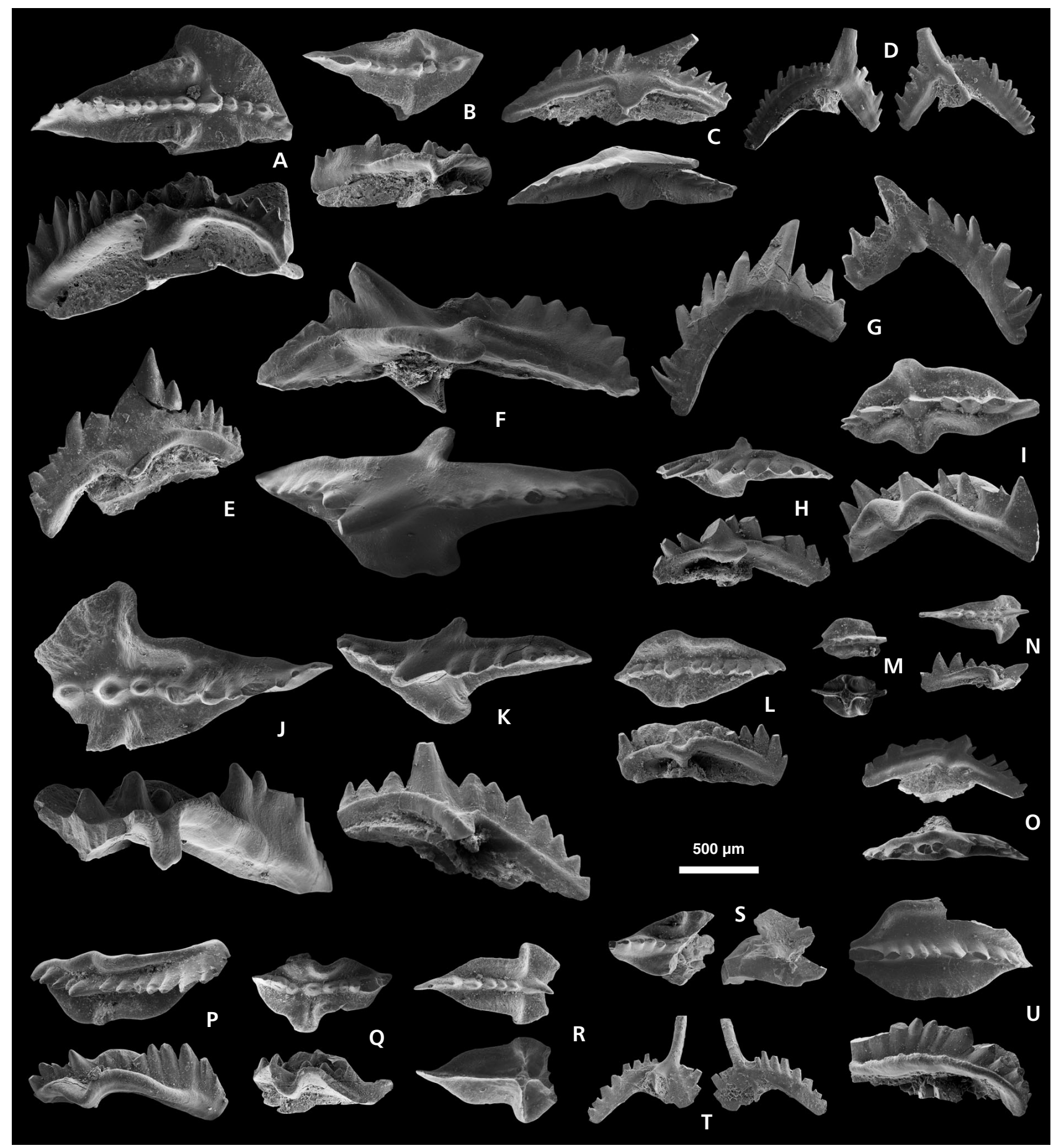

Figure 3. A-U - Polygnathoides siluricus Branson \& Mehl, 1933. A, B - upper and lateral views of Pa elements with basal fillings, sample 5Po15t. - C - lateral and upper view of Pb element with basal filling, sample 5Po15t. $\bullet \mathrm{D}$ - outer and inner lateral view of Sb? element, sample 5Po15t. $\bullet$ E - lateral view of $\mathrm{Pb}$ element with basal filling, sample 5Po17. $\bullet \mathrm{F}$ - lateral and upper view of Pb element, sample $5 \mathrm{Po} 20 . \bullet \mathrm{G}-$ outer and inner lateral view of Sb? element, sample 5Po20. $\bullet \mathrm{H}$ - upper and lateral view of Pb element with basal filling, sample 5Po32. • I - upper and lateral view of Pa element, sample 5Po32. • J - upper and lateral view of incomplete Pa element, sample 5Po20. $\bullet \mathrm{K}-$ upper and lateral view of Pb element with basal filling, sample 5Po20. $\cdot \mathrm{L}$ - upper and lateral view of Pa element with basal filling, sample 5Po32. $\bullet \mathrm{M}-$ upper and lower view of Pa element, sample 5Po33. $\bullet \mathrm{N}-$ upper and lateral view of incomplete Pa element, sample 5Po32. $\bullet \mathrm{O}$ - lateral and upper view of Pb element with basal filling, sample 5Po32. $\bullet$ P - upper and lateral view of Pa element, sample 5Po33. $\bullet \mathrm{Q}$ - upper and lateral view of Pa element with basal filling, sample 5Po33. $\bullet$ - upper and lower view of incomplete Pa element, sample 5Po32. $\bullet \mathrm{S}$ - upper and lower view of incomplete Pa element with basal filling, sample 5Po33. $\bullet \mathrm{T}-$ inner and outer view of Sb? element, sample 5Po33. • U - upper and lateral view of incomplete Pa element with basal filling, sample 5Po33. All specimens are deposited in the collection of Ladislav Slavík at the Institute of Geology AS CR, v.v.i. All figures are the same scale (scale bar equals $500 \mu \mathrm{m}$ ). 
interval in the Požáry Quarries is temporarily stored at the collection of L. Slavík at the Institute of Geology AS CR, v.v.i. and will be later deposited in the National Museum, Prague.

\section{Conodont faunas of the siluricus Zone and immediate post-siluricus interval from the Požáry section}

The conodont zonation established by Schönlaub in the Ludfordian is partly confirmed by the recent sampling, however, some previously published data must be clarified. Taxon Ancoradella ploeckensis has been reported by Schönlaub from 0.77-0.63 m below the top of bed No. 15 at Požáry section (Schönlaub in Kříž et al. 1986, p. 336); in the same page he reports Polygnathoides siluricus from the base of bed. No. 15. A. ploeckensis was also found at the base of bed No. 1 in the Marble Quarry in Lochkov (ibidem). Lehnert et al. (2007a, p. 238) used Schönlaub's published conodont data and quoted the FAD of $P$. siluricus from the same level $(0.77-0.63 \mathrm{~m}$ below the top of bed No. 15) as FAD of A. ploeckensis (quoting the same work). This is probably a misprint that also appeared in their figure (Lehnert et al. 2007a, text-fig. 8). Although, the occurrence of Ancoradella ploeckensis was not confirmed by the recent sampling, one of us (L. Slavík) examined the specimens in the conodont collection of H.P. Schönlaub at Geologische Bundesanstalt, Wien. In the conodont cell described as "v.15 Poz. 63-77cm" are present four Pa elements of A. ploeckensis.

In general, the preservation of conodont elements in all studied samples is mostly excellent without recrystallization and bleaching. The dark brown colour (CAI up to 4) consistently appears in most mature Pa elements. A good preservation of the basal filling can be observed, e.g. in P. siluricus, Ozarkodina typica, Wurmiella and even in some ramiform elements of Kockelella. All these overall characters of preservation negate assumptions for conodont reworking, although it cannot be excluded. For better transparency, the following characterization of the newly obtained conodont material is divided into paragraphs by genera:

\section{Polygnathoides}

The most prominent and zonally diagnostic taxon Polygnathoides siluricus Branson \& Mehl, 1933 was found in six samples. The concept of the cosmopolitan taxon includes the Pa element - a very distinctive and easily identifiable worldwide, and some other elements (see Fig. 3). The former taxon Polygnathoides emarginatus (Branson \& Mehl, 1933) is here considered as the Pb element of $P$. silu- ricus apparatus. The possibility of affiliation of $P$. emarginatus to $P$. siluricus has already been mentioned by Klapper \& Murphy (1974, p. 56). Schönlaub treated P. siluricus and $P$. emarginatus separated but showed their strikingly corresponding range (in Chlupáč et al. 1980, text-fig. 6 Mušlovka Quarry, and in Kříž et al. 1986, text-fig. 13 Marble Quarry).

Kleffner (1989) in his worldwide graphic correlation also kept both taxa separated and showed somewhat longer range of $P$. emarginatus ( $c f$. Cellon section; Walliser 1964). This might be, however, caused by sampling failure in few localities, where the basal ranges of both taxa do not precisely overlap. Polygnathoides emarginatus was later accepted by several authors (e.g., Serpagli et al. 1998) as the P2 element of $P$. siluricus. Jeppsson (1983, text-fig. 1a-e) presented his "improved concept" of the apparatus of $P$. siluricus. Because the element associations from the present conodont collection are not similar, his reconstruction is not followed in this paper. With the exception of the Pa element, the other members of the apparatus regarded by Jeppsson as coinciding are not convincing from the figures. In the Požáry section, several Sb elements in association with $\mathrm{Pa}$ elements of $P$. siluricus were found; these are believed to belong to the apparatus (see Fig. 3D, G, T). Other elements of the apparatus are, however, not certain from the available material. Moreover the yields of $P$. siluricus in samples are not large enough to have probability of complete apparatus.

In contrast to above-mentioned data of H.P. Schönlaub, the lowest find of $P$. siluricus is in sample 5Po15t in the upper part of bed No. 15. The interval of the composite sample is $85-130 \mathrm{~cm}$ above the base (Fig. 2). The numbers of identified elements of $P$. siluricus vary in samples from 1 to 11 . Observed from the representative figures, the $\mathrm{Pa}, \mathrm{Pb}$ and $\mathrm{Sb}$ elements are relatively large in the lower part of the recorded siluricus range (i.e. from bed No. 15 to bed No. 20). Pa elements show very distinctive crease in the middle part of platform. The younger elements from beds Nos. 32 and 33 are apparently smaller. These small forms (see Fig. 3L-U) re-appear after a short interruption of the taxon range in sample 5Po28 in which the known elements of the apparatus are missing.

\section{Kockelella}

Representatives of the genus Kockelella Walliser, 1957 occur in the major part of the recorded $P$. siluricus range and show relatively high variability, although the numbers of specimens in samples are rather low. Taxa of Kockelella are found at the base of bed No. 15 (sample 5Po15, Fig. 2), i.e. together with $P$. siluricus as reported Schönlaub (in Kř́ž et al. 1986, p. 336). The most recent reconstruction of phylogeny and revised taxonomy of the genus Kockelella 
is provided by Serpagli \& Corradini (1999). The stratigraphic ranges of the individual taxa mostly coincide with their global ranges with exception of $K$. variabilis variabilis Walliser, 1957.

In contrast to global range of $K . v$ variabilis that was assumed to disappear before the entry of $P$. siluricus (e.g., Barrick \& Klapper 1976, Serpagli \& Corradini 1999), this taxon ranges high into the siluricus Zone in Bohemia as showed Schönlaub [in Chlupáč et al. (1980), text-fig. 6 Mušlovka Quarry and this paper (Fig. 2)]. The specimens (Fig. 4B, J, L, V) have obviously no fusion of denticles as it is in K. v. ichnusae Serpagli \& Corradini, 1998. Apart from a few interruptions, the ranges of all taxa of Kockelella K. v. variabilis, K. v. ichnusae and K. maenniki Serpagli \& Corradini, 1998 have identical ranges in the Požáry section: All taxa of Kockelella enter with P. siluricus (base of bed No. 15, Schönlaub in Chlupáč et al. 1980) and disappear above bed No. 28. The local specific variability in the genus is constant during its entire range. A marked change can be seen only in the size of the Pa elements. In sample 5Po28 (the LAD of Kockelella), the size of the specimens considerably decreases: Typically small Pa elements from sample 5Po28 are on Fig. 4-M, N. Apart from Pa elements, several members of the Kockelella apparatus $(\mathrm{Pb}, \mathrm{Sa}, \mathrm{Sb}$, Sc) were identified (see Fig. 4) following the reconstruction given by Serpagli \& Corradini (1999). The specific affiliation of these elements is not possible due to mixed apparatuses in samples and similarity of non-Pa elements within the genus.

\section{Ozarkodina}

Ozarkodina typica Branson \& Mehl, 1933 is the only representative of the genus Ozarkodina Branson \& Mehl, 1933 that was found in the studied interval. The name $O z$. confluens that has been used by many authors for the same taxon is abandoned in this paper; for thorough explanation and discussion see Murphy et al. (2004) who provided a new classification of late Silurian-early Devonian Spathognathodontidae. Following their revision, the taxa $O z$.? crispa and $O z$.? snajdri are with question mark, because their assignment to the genus Ozarkodina is not certain. The high variability in Ozarkodina typica within the siluricus Zone is a global feature. Klapper \& Murphy (1974) discriminated several morphotypes in Nevada; the ranges of their alpha, beta and gamma morphotypes overlap with $P$. siluricus.

However, in the material from the Požáry section, few forms resemble those figured from Nevada (e.g., Klapper \& Murphy 1974, pl. 3, fig. 15); and shows that there exists large regional differences in morphologies driven by paleoecology. Viira $(1983,1994,2000)$ described several late Silurian taxa that can be assigned to Ozarkodina in the sense of Murphy et al. (2004). Some hints of typical morphologies in Pa elements as in e.g., Ozarkodina nasuta (Viira, 1983) - a latest Silurian taxon with characteristically fused anterior fan on the blade, can be observed also in some specimens from the Požáry section (e.g., Fig. 5B, G, J). Several specimens almost precisely coincide with those already figured in the literature, e.g., specimens on Fig. 5G, J are almost identical to those figured by Jeppsson (1974, pl. 5, fig. 9). However, the specimens obtained are too variable and in spite of certain common patterns mentioned above, still largely differ both from the taxa that have already been formally named, or from informally established morphotypes. Moreover, a high variability but insufficient number of Pa elements obtained up to now from the material do not allow introduction of new taxa. Therefore, Ozarkodina typica is used here in sensu lato, because of variation as shown on Fig. 5.

Author's impression from the obtained specimens tends rather to intra-specific variability that caused the number of coexisting slightly diverse forms. On the first sight, the highest variability can be seen in sample 5Po15t: the specimens (Fig. 5D-N) are robust and large with variable cockscomb and denticulation pattern. The proportions of the element (length/width ratio) are not changed. The same degree of variability can be also observed in younger levels (e.g., bed Nos. 17, 20, see specimens on Fig. 5), but the overall impression can be largely biased by changing numbers of obtained specimens ( $c f$. Fig. 2). Ozarkodina typica ranges with interruption (lacking in beds Nos. 32 and 33) up to top of bed No. 34. Its range is then interrupted for a long period: it reappears in bed No. 87 at the end of Pedavis latialatus range within the crispa Zone (Carls et $a l .2005$, text-fig. 2). The general features of the specimens from Požáry section comply with the diagnosis of the genus Ozarkodina according to revision by Murphy et al. (2004): In the Pa element, the position of the basal cavity is almost in the mid-point of the length, the basal cavity and the platform lobes are very small. Herein it is necessary to note that many figured specimens have basal filling that may cause impression of a larger basal cavity, than in reality. The distribution of white matter is an important feature in Ozarkodina ( $c f$. figures in Jeppsson 1974). It was observed in specimens before coating for SEM images: In most specimens it is difficult to see the real distribution of white matter near the lower margin even by using higher intensity of light. In general, this observation is influenced by size of the element (maturity) and light intensity. In this case, however, the CAI value is too high that practically obscures the observation.

The other elements of the Ozarkodina apparatus are not frequent in samples; with certainty can be distinguished $\mathrm{Pb}$ and Sb elements (Fig. 5Z) that correspond to specimens from Bainbridge Limestone figured by Murphy et al. (2004). These specimens also comply with the figured ap- 
paratus from Mušlovka Quarry (Schönlaub in Chlupáč 1980, pl. 17, fig. 21). The affiliation of other elements (e.g., Sa element on Fig. 4S with basal filling) or scarcely found fragmented Sc and M elements found in few samples (these are not figured) is not certain.

\section{Wurmiella}

The genus Wurmiella Murphy, Valenzuela-Ríos \& Carls, 2004 is represented by a large number of specimens (up to $100 \mathrm{~Pa}$ elements in sample 5Po20, see Fig. 2). The dominating taxa belong to Wurmiella excavata (Branson \& Mehl, 1933), herein used in sensu lato because there are differences in angulation of lower margin of the Pa element between the typical material and the material obtained from the Požáry section.

The concept of Wurmiella and its apparatus reconstruction herein agrees with that of Murphy et al. (2004). A selection of specimens of $W$. excavata from different samples across the sampled interval is figured on Fig. 6. These representative specimens were selected in order to show possible variability in the material. From the figures it is, however, obvious that the variability, if any, is very low. The variation in denticulation is rather low; the general pattern with prominent cusp inclined posteriorly is present in all specimens, as well as the presence of larger denticles in the anterior part of the blade. The basal cavity with characteristic shape is always at the same position in the posterior half of the blade. The only marked difference, i.e. changing number of denticles, largely depends on stage of maturity: juvenile specimens have considerably lower number of denticles than the mature ones ( $c f$. Fig. 6). The only four $\mathrm{Pa}$ elements of Wurmiella found in the sampled interval in Požáry section are distinctly different from those of $W$. excavata. These were assigned to Wurmiella cf. inclinata (Rhodes, 1953). The spacing of denticulation is similar as in specimen figured by Rexroad \& Craig (1971, pl. 80, fig. $25)$ that was designated as neotype of $W$. inclinata by Murphy et al. (2004). The specimen figured herein (Fig. $6 \mathrm{U})$ is however juvenile, therefore not decisive, similarly as the only specimen from the top of bed No. 34. The two Pa elements from bed No. 28 were larger but had been broken during processing. They however, differ from $W$. inclinata by almost even lower margin. Accordingly, these specimens are treated in open nomenclature. Wurmiella excavata is very successful component of conodont faunas as it occurs continuously in all samples without interruption and practically without significant variability in the studied part of the section. The previous studies also showed its uninterrupted range in the upper Ludlow in the Požáry section (Carls et al. 2005).

\section{Delotaxis}

The specimens of Delotaxis Klapper \& Philip, 1971 occur continuously from bed No. 20 up to the end of the sampled interval. Following the experience from the Barrandian conodont collections, the use of the genus name "Delota$x i s$ " for the late Silurian-early Devonian group of prioniodinacean taxa is preferred rather than name "Oulodus Branson \& Mehl 1933". Delotaxis is based on the late Silurian type species formerly named as Ligonodina elegans Walliser, 1964. According to Jeppsson (1969) and Walliser (1972) the concept employs an apparatus with five pairs of different elements. This concept of Delotaxis is herein considered to be closer to prioniodinacean taxa occurring during the late Silurian than the concept of the genus Oulodus with sexmembrate apparatus in the sense of Sweet \& Schönlaub (1975) who synonymized Delotaxis with Oulodus. Their concept comprises taxa from a long stratigraphic interval with Middle Ordovician type species (Oulodus serratus). The numbers of obtained elements of Delotaxis from the Ludfordian of the Požáry section are mostly small with exception of sample 5Po34t (40 fragmented elements). The material in general is rather poor and often fragmented. Therefore a specific determination is impossible and the specimens obtained were mostly unsuitable for imaging. Most of the specimens probably belong to Delotaxis ex gr. silurica (Branson \& Mehl, 1933).

Figure 4. A, E - Kockelella variabilis ichnusae Serpagli \& Corradini, 1998; upper and lower view of incomplete Pa elements, sample 5Po15. - D, K, M - Kockelella variabilis ichnusae Serpagli \& Corradini, 1998; (D) upper and lower view of Pa element, sample 5Po15, (K) upper and lower view of Pa element, sample 5Po20, (M) upper view of Pa element, sample 28. • B, J, L, V - Kockelella variabilis variabilis Walliser, 1957; (B) upper and lower view of Pa element, sample 5Po15, (J, L) upper and lower view of Pa elements, sample 5Po20, (V) upper and lower view of Pa fragment, sample 5Po28. • C, O, N - Kockelella maenniki Serpagli \& Corradini, 1998, (C) upper and lower view of Pa element, sample 5Po15, (O,N) upper and lower view of Pa elements, sample 5Po28. • F - lateral view of Pb element of Kockelella. $\bullet \mathrm{G}, \mathrm{H}-\mathrm{Sc}$ elements of Kockelella, (G) inner-lateral and outer-upper view, (H) inner-lateral view, sample 5Po15t. • I, Q - lateral view of Sa elements of Kockelella, sample 5Po24 (I), sample 5Po20 (Q). - P - inner-lateral view and outer-upper view of an unknown element, probably aberrant form, sample 5Po15t (cf. Walliser 1964, Pl. 10, fig. 18). - R, U - lateral view of Sb? elements of Kockelella, sample 5Po24 (R), sample 5Po20 (U). • S - unidentified trichonodellan (Sa) element with basal filing, sample 5Po24, it might belong to Ozarkodina. • T - upper and lower view of unknown, probably aberrant element, sample 5Po28 (cf. Walliser 1964, pl. 10, fig. 19). All specimens are deposited in the collection of Ladislav Slavík at the Institute of Geology AS CR, v.v.i. All figures are the same scale (scale bar equals $500 \mu \mathrm{m}$ ). 


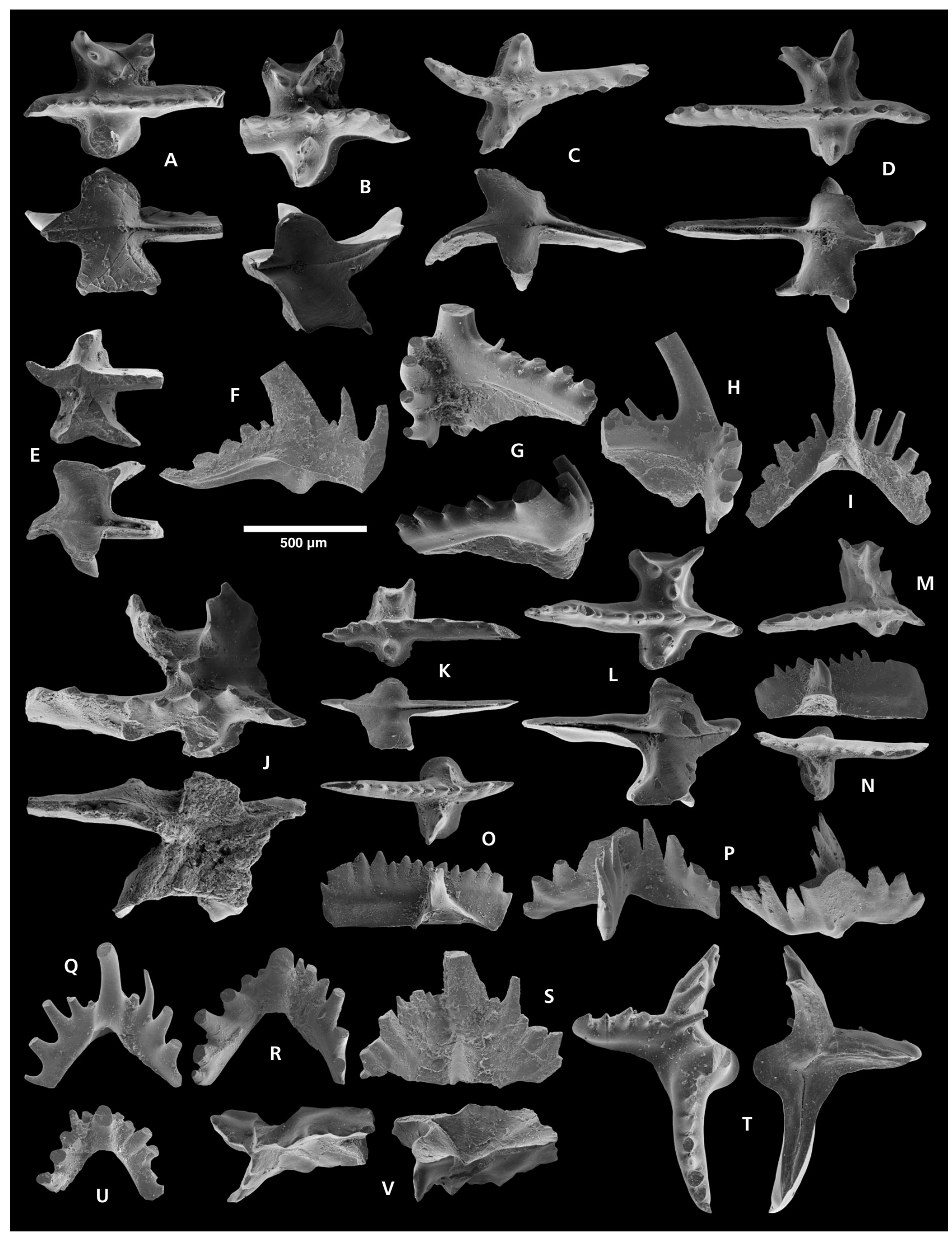




\section{Coniform elements}

Simple cone elements are extremely rare in the sampled interval, especially in its lower part. Among this group of conodonts Panderodus unicostatus (Branson \& Mehl, 1933) dominates. This specific determination of Panderodus, however, cannot be absolutely certain, because of many morphologically identical specimens that occur in large stratigraphic interval globally (e.g., Middle Devonian).

Few specimens of Pseudooneotodus beckmanni (Bischoff \& Sannemann, 1958) were identified in the upper part of the sampled section (from bed No. 35). The taxon start to occur in larger numbers at this stratigraphic level (Ludfordian) as showed by Corradini (2007, text-fig. 2) based on material from Italy. Three tiny elements of Belodella were found only in one sample (5Po24). The stratigraphic significance of these coniform elements is in general very low, but the considerably low numbers point to well washed out sediment, when these tiny subtle elements were transported away.

\section{Anomalous elements}

In the siluricus Zone of the Požáry section several anomalous forms occur. The specimen on Fig. 4P resembles the specimen figured by Walliser (1964, pl. 10, fig. 18) from the Cellon section, Carnic Alps. The specimen of Fig. 4T resembles the specimens figured by Walliser (1964, pl. 10, fig. 19) from Cellon and by Klapper \& Murphy (1974, pl. 10, fig. 17) from Pete Hanson Creek section II E, Nevada. Both specimens from the Cellon section figured by Walliser under the name Lonchodina walliseri Ziegler, 1960 are from the siluricus Zone. The number of different anomalous forms found in the Cellon section is relativelly high in contrast to only two (figured) specimens from the Požáry section. The specimen of Klapper and Murphy mentioned above probably also comes from the siluricus Zone. These specimens are characterized by presence of an extra process. High numbers of these anomalous conodont elements from the siluricus Zone were also reported from Sardinia by Corradini et al. (1995). They interpreted the increased frequency of the anomalous elements as a result of effects of the Primo-episode according to the oceanic model of Jeppsson (1990). This episode is thought to be characterized by higher nutrient supply that supports higher diversity in planktonic communities leading to higher diversification within subsequent part of food chain.

The probability of occurrence of anomalous elements is increased in highly diversified faunas as it has been summarized by Corradini et al. (1995, 2009). They suggested two hypotheses about existence of the anomalous forms: they either represent the usual percentage of pathological forms in a normal population or they are rather "evolutionary tests" that were quickly stopped during oceanic events. The only two anomalous specimens from the Požáry section just confirm the existence of morphologically identical anomalous forms in different areas.

\section{Summary of conodont data around the siluricus Zone from the Prague Basin}

The taxon Polygnathoides siluricus Branson \& Mehl, 1933, has been reported from many regions of the world (for summary see Jeppsson 1974). Since the introduction of Walliser's zonation in 1964, the siluricus Zone became a stratigraphic unit with universal use and as well one of the best working conodont biozones in the entire Silurian. In general, it represents a time-interval with thriving conodont faunas characterized by high taxonomic diversity and high intra-specific variability.

Schönlaub (in Chlupáč et al. 1980) provided conodont data from the Mušlovka Quarry that lies about $500 \mathrm{~m} \mathrm{NE}$ from the Požáry section. Its Ludfordian part is almost identical to the Požáry one, as regards sedimentology, thickness and faunal content ( $c f$. Křiž 1992). The conodont succession of Mušlovka also corresponds to that in the Požáry section. In the Mušlovka Quarry, the range of $P$. siluricus ends at precisely the same level as in the Požáry section, where the corresponding level is the boundary between beds Nos. 33 and 34 ( $c f$. Chlupáč et al. 1980, text-fig. 6).

According to data provided by Schönlaub, Ozarkodina typica ( $=O z$. confluens of Schönlaub) ranges in the Mušlovka Quarry up to the same level, i.e. to the base of the horizon with the trilobite Ananaspis fecunda that approximates the base of the P. latilobus graptolite Zone. At this level the range of conodont taxon is interrupted and then lacks in a long interval, similarly like in the Požáry section. In the Mušlovka Quarry Kockelella is shown to range up to the level with the last $P$. siluricus. The same overlap of Kockelella and Polygnathoides was demonstrated from the Marble Quarry in Lochkov (Kř́̌ž et al. 1986, text-fig. 13). This section is however affected with a large stratigraphic gap and reduced carbonate accumulation ( $c f$. Kříž et al. 1986, text-fig. 12; Manda \& Kř́žz 2006, text-fig. 3). The figured specimens of Schönlaub (in Chlupáč et al. 1980, pl. 17, text-figs $1-5,21$ ) are corresponding both in morphology and size proportions to specimens from the Požáry section from respective stratigraphic levels (e.g., very small Pa element of $P$. siluricus from the end of its range figured from the Mušlovka Quarry, ibidem). The uninterrupted ranges of Wurmiella and Delotaxis in the Požáry section are confirmed also in the Mušlovka Quarry.

The conodonts in sections from deeper environments are usually very scarce as have proved previous studies 


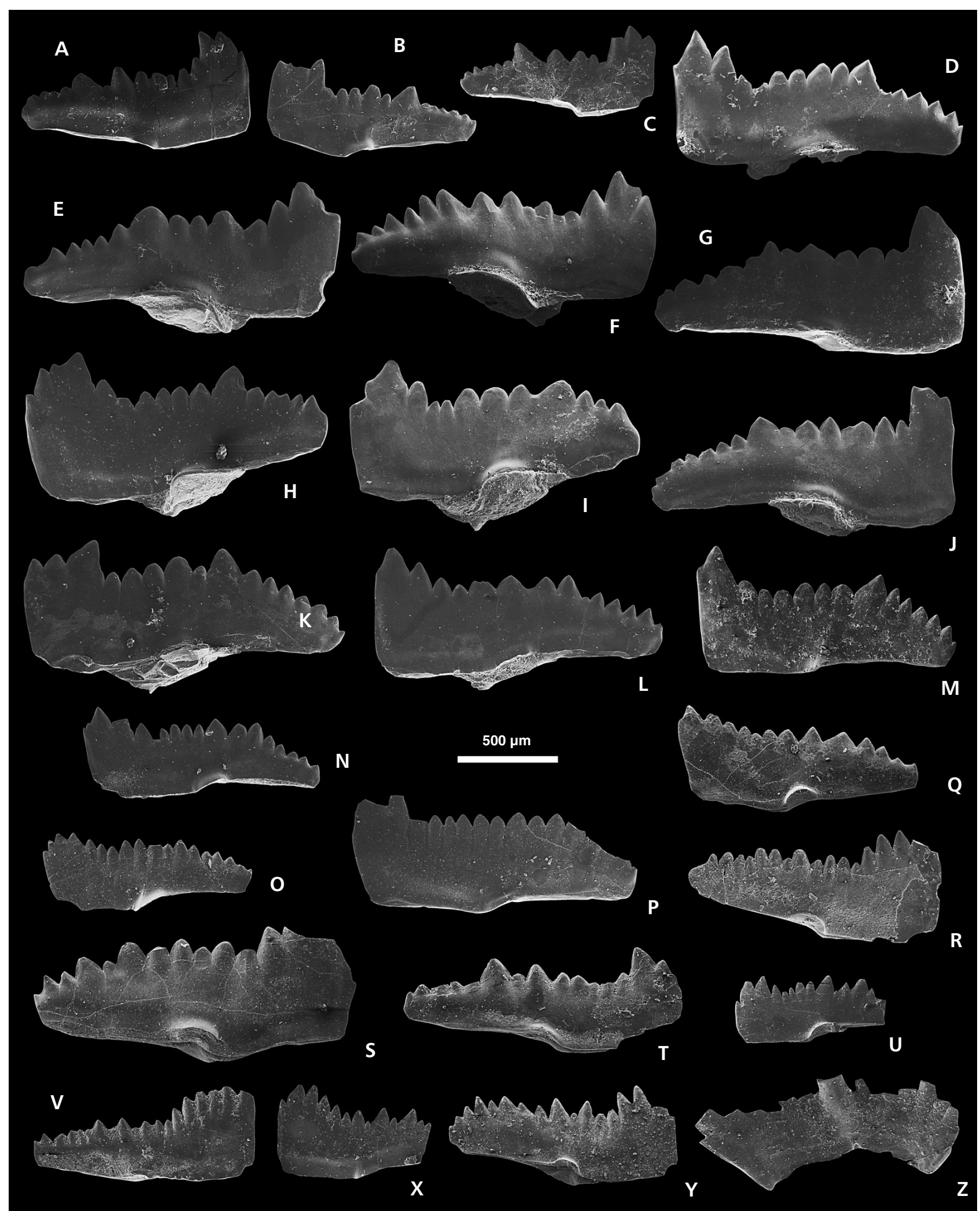

Figure 5. A-Z - Ozarkodina typica Branson \& Mehl, 1933 sensu lato. $\bullet$ A-Y lateral views of Pa elements. $\bullet$ A-C - from sample 5Po15. $\bullet$ D-N - from sample 5Po15t. $\bullet \mathrm{O}-\mathrm{Q}, \mathrm{S}-$ from sample 5Po17. $\bullet \mathrm{R}, \mathrm{T}-\mathrm{V}$ - from sample 5Po20. $\bullet \mathrm{U}$ - from sample 5Po24. $\bullet \mathrm{X}$ - from sample 5Po28. $\bullet \mathrm{Y}-$ from sample 5Po34. $\bullet \mathrm{Z}$ - inner lateral view of Sb element from sample 5Po34. Note the basal fillings present on some specimens. All specimens are deposited in the collection of Ladislav Slavík at the Institute of Geology AS CR, v.v.i. All figures are the same scale (scale bar equals $500 \mu \mathrm{m}$ ). 
(cf. data in Kř́žz 1992, Lehnert et al. 2007a). Accordingly, it is mostly impossible to recognize the true ranges of taxa. This concerns also the index taxon that is rather scarce; only one specimen of $P$. siluricus was found in the Kosov section (Lehnert et al. 2007a). A single specimen of the index was found also in the Všeradice section (Manda et al. in preparation). As regards graptolite faunas, the upper part of the range of Saetograptus linearis overlaps with the basal part of the siluricus Zone at Mušlovka (Kř́ž 1992, text-fig. 72); it corresponds to bed No. 15 in the Požáry section. The taxon is approximately coeval with S. leintwardinensis (see Kleffner 1989, p. 911; Kleffner 1995, fig. 7) that has been recognized in Gotland (Jeppsson et al. 2006, text-fig. 1). In the Barrandian, N. kozlowskii has been found in deeper facies only (e.g., Kosov Quarry, Štorch 1995b). Although it is lacking in the shallow water sections (e.g., Požáry section, Mušlovka Quarry), the time level of N. kozlowskii in the Požáry section can be approximated: the benthic faunas coeval to N. kozlowskii are present in beds Nos. 33 and 34 (Kř́ž 1998).

\section{Correlation with Gottland and other areas}

A detailed comparison and evaluation of conodont faunas from the Prague Basin with those from Gotland is not easy, because on Gottland, the stratigraphic framework consists of mostly complicated composite sections and localities with ranges of conodont taxa that have not yet been joined in a standard. Apart from some exceptions listed below, the critical specimens reflecting the Lau Event from Gotland have not been figured or re-figured in recent papers. Some specimens related to the time of the Event are scattered in several papers (e.g., Jeppsson 1972, text-fig. 1, pl. 1 - part and Jeppsson 1983, fig. 1 - part). The figured taxa including "Hindeodella excavata" [= Wurmiella excavata (Branson \& Mehl)], "Ligonodina excavata excavata" Branson \& Mehl [=?Delotaxis silurica (Branson \& Mehl)] and "Hindeodella confluens" [= Ozarkodina typica Branson \& Mehl], Distomodus dubius Rhodes [= Coryssognathus dubius (Rhodes)], Pelekysgnathus dubius Jeppsson, n. sp. and Gen. et. sp. indet. of Jeppsson (1983) [= Silurognathus maximus Jeppsson, 2005] - an endemic taxon from Gotland, and Polygnathoides siluricus figured by Jeppsson (1983, text-fig. 1a only). The figured specimens mentioned above are from several different localities around Gotland and Skåne corresponding to siluricus Zone and latialatus Zone (= ?Icriodontid Z.). As shown above, taxonomic names of some conodont taxa have been changed (in some cases even repeatedly) during the last four decades. But in spite of some difficulties with detailed correlation due to sparse documentation of updated conodont data and certain specificity of Baltic faunas in general, there is a good base for biostratigraphic bracketing of the Lau Event in both areas: Jeppsson (2005) provided a detailed revision of conodont stratigraphy on Gotland with characterization of local biozones. His zonal framework enables relative time correlation between regions as shown also improved correlation with Australia (Jeppsson et al. 2007).

There are, however, marked differences in the succession of stratigraphically significant cosmopolitan taxa between Bohemia and Gotland. This concerns especially the range of Kockelella on Gotland where only the last $K$. $v$. variabilis overlap with the first $P$. siluricus ( $c f$. Jeppsson 2005 , p. 275). However, in many other areas the upper range of Kockelella largely overlaps with the range of $P$. siluricus (Walliser 1964, tab. 2; cf. also correlation by Kleffner 1989, text-fig. 6 and Kleffner 1995, text-fig. 7; Serpagli \& Corradini 1999, text-fig. 1). It applies also to the conodont data from the Prague Basin presented in this paper. This might suggest either a paleoecological reason for a longer survival of Kockelella on Gotland or, the possibility that $P$. siluricus starts elsewhere much earlier than it has been found on Gotland as mentioned by Jeppsson (2005, p. 275), where only the uppermost part of the short zone might be recorded. The latter possibility seems to be more likely.

As Jeppsson (2005) remarked, in some areas including Cellon (the Carnic Alps), A. ploeckensis ranges into succeeding siluricus Zone. The very short overlap of A. ploeckensis and P. siluricus in the Bohemian sections is recorded within the upper range of $S$. linearis that corresponds to S. leintwardinensis in Baltica and Avalonia. Because of the facies development and lack of carbonate layers, the exact range of $A$. ploeckensis cannot be tested in the Požáry section or Mušlovka Quarry. But this very short overlap indicates that the siluricus Zone may also begin earlier than its local entry at the base of bed No. 15 in the Požáry section (Kříž et al. 1986). On Gotland, these conodont taxa do not overlap at all, as $P$. siluricus was recorded well above the range of A. ploeckensis (Jeppsson 2005). The interval of possible overlap on Gotland could be expected at the level with $S$. leintwardinensis, but note that the sequence of graptolite zones $B . b$. tenuis and $S$. leintwardinensis is not in correct order on figure by Jeppsson et al. (2006, text-fig. 1).

Apart from the conodont taxa mentioned above, no other stratigraphically important species occurring in both regions are available from the strata preceding the Lau Event. If we correlate this limited succession of conodonts from the shallower sections in Bohemia and Gotland with support of graptolite zonal equivalents ( $S$. linearis in Bohemia $=S$. leintwardinensis on Gotland), the lower part of $P$. siluricus range starting with bed No. 15 in the Požáry section probably corresponds to the Ethelem Secundo Episode or even to interval as low as the Linde Event of Jeppsson et al. (2006, text-fig. 1), where Ancoradella, Kockelella and 


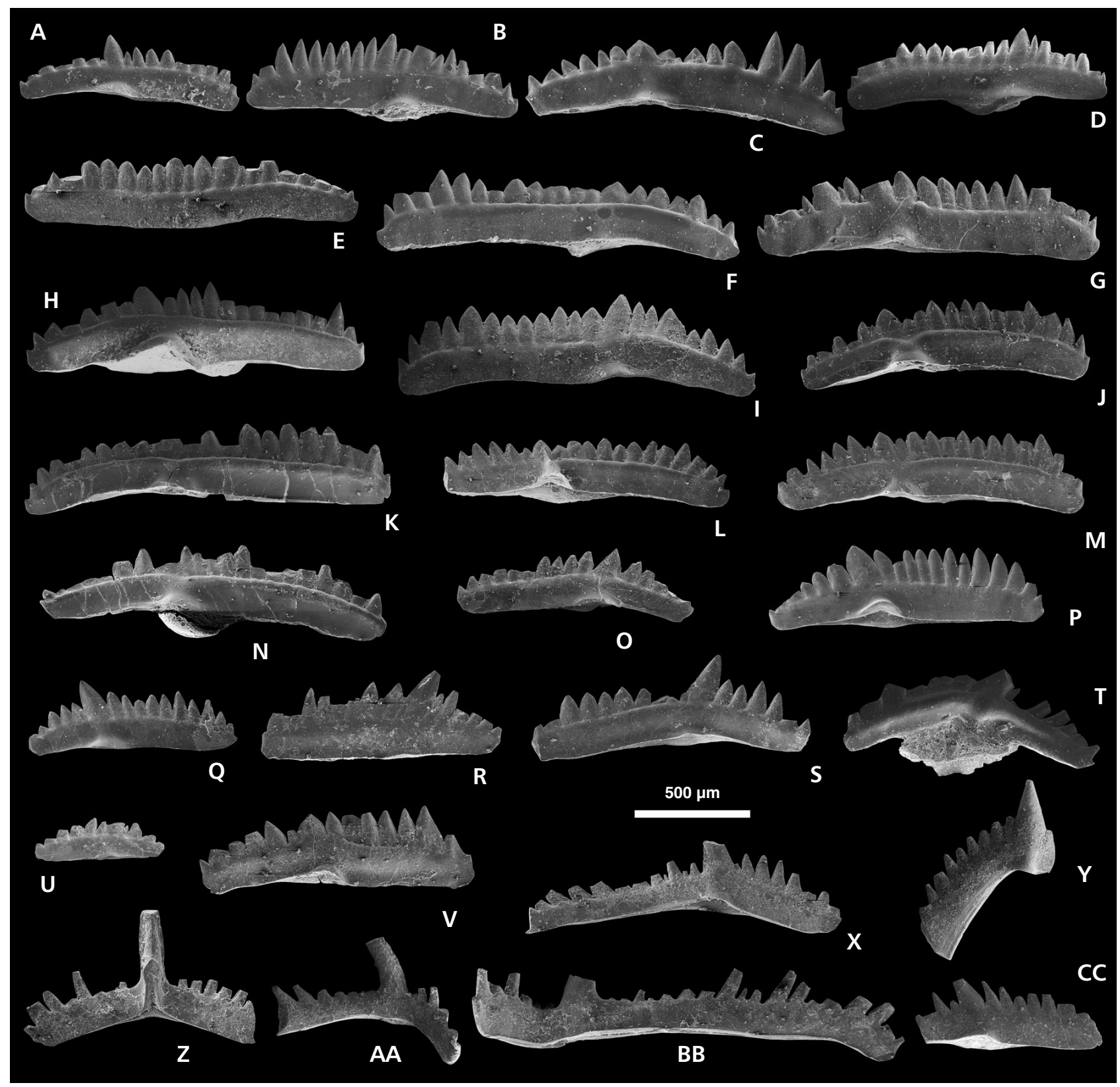

Figure 6. A-T, V-CC - Wurmiella excavata (Branson \& Mehl, 1933) sensu lato. • A-C -lateral views of Pa elements from sample 5Po15t. $\cdot$ D-I - lateral views of Pa elements from sample 5Po17. $\bullet \mathrm{J}-\mathrm{N}$ - lateral views of Pa elements from sample 5Po20. $\bullet$ O lateral view of Pa element from sample 5Po24. $\bullet \mathrm{P}-\mathrm{R}$ - lateral views of Pa elements from sample 5Po28. $\bullet \mathrm{S}$ - lateral view of Pa element from sample 5Po32. $\bullet \mathrm{T}-$ lateral view of $\mathrm{Pb}$ element from sample 5Po32. $\bullet \mathrm{V}, \mathrm{CC}-$ lateral views of Pa elements from sample 5Po34. $\bullet \mathrm{X}$ - lateral view of Pb element from sample 5Po34. $\bullet \mathrm{Y}-$ lateral view of M element from sample 5Po34. $\bullet Z$ - lateral view of Sa element from sample 5Po34. AA - lateral view of incomplete Sb element from sample 5Po34. BB - lateral view of Sc element from sample 5Po34. • U - Wurmiella cf. inclinata? (Rhodes, 1953), lateral view of Pa element from sample 5Po33. All specimens are deposited in the collection of Ladislav Slavík at the Institute of Geology AS CR, v.v.i. All figures are the same scale (scale bar equals $500 \mu \mathrm{m})$.

later also Polygnathoides may overlap. Jeppsson (2005) interpreted the intermittent appearances of the representatives of the above three genera as competition for the same paleoecological niche. The data from other areas (e.g. Cellon) however show a relatively long coexistence of Kockelella with both Ancoradella and Polygnathoides. A single find of $P$. siluricus at the earliest Linde Event (Jeppsson 2005, p. 275) may correspond to the early find of a $\mathrm{Pb}$ element (= formerly $P$. emarginatus) deep in the $A$. ploeckensis Zone in the Cellon section. The middle and upper part of the recorded $P$. siluricus range (approximately up to bed No. 30) with very diverse faunas is probably 
equivalent of the lower Havdhem Primo Episode, where $S$. maximus Jeppsson, 2005 occurs. The short range of $P$. siluricus already without Kockelella in the Požáry section (beds Nos. 32 and 33) then may correspond to upper part of Havdhem Primo Episode. These strata are also approximately correlated with $N$. kozlowskii in both regions. The large interval with $P$. siluricus Zone within N. kozlowskii Zone on Gotland (Jeppsson et al. 2006, text-fig. 1) and the short range of siluricus without Kockelella in the Požáry section (in contrast to Gotland) points to the absence of large upper part of $P$. siluricus Zone in the Požáry and Mušlovka sections.

According to Lehnert et al. (2007a), the shallowest part of the Požáry section is in beds Nos. 33 and 34 (i.e. the beds with $N$. kozlowskii faunal equivalents), where reduced sedimentation with possible gaps can be expected. The interval just above bed No. 34 in the Požáry section can be well correlated with the interval above bed No. 16 in the Mušlovka Quarry where the upper sequence boundary with gaps was documented (Manda 2003).

In the Mušlovka Quarry, Oz.? snajdri is recorded $4 \mathrm{~m}$ above the last $P$. siluricus. It corresponds approximately to level above bed No. 49 (comparing lithology and thickness) in the Požáry section, where, $1.5 \mathrm{~m}$ above this level (in bed No. 62), Ped. latialatus with Oz.? snajdri were found (Carls et al. 2005). The fauna at this level contains also Parazieglerodina plodowski Carls et al., 2005 with incipient alternating denticulation in ramiform elements. This functional step probably reflects proceeding recovery of conodont faunas testing new morphologies on ramiform elements. The icriodontid elements (Ped. latialatus) are very scarce globally and the real entry of Pedavis thus cannot be detected. The entry of Oz.? snajdri might be also expected lower than it was recorded, i.e. close above the LAD of P. siluricus. Similarly as in the Cellon section, the fauna with Pedavis latialatus can be correlated with Icriodontid Subzone on Gotland. In the Požáry section this level is already in interval affected with sea-level rise correlated with the upper P. latilobus graptolite Zone in Bohemia ( $c f$. Manda \& Kř́rž 2006).

\section{Discussion on position of the Lau Event in the Požáry section}

In strata from the bed No. 34 upwards in the Požáry section, a small change in conodont faunas with already decreased element frequency is observed. It is characterized practically only by disappearance of $P$. siluricus (Kockelella disappeared earlier). Its absence in few samples that instantly follow might be however still caused by sampling failure that can be larger with decreasing populations of the taxon. The change itself in the section across the critical in- terval is not severe if the continuous ranges of taxa are considered. The following gradual deepening above bed No. 35 where the major change in macrofauna is observed (Manda \& Kř́ž 2006) did not affect the continuity of ranges of taxa like Oz. typica, W. excavata or Delotaxis ex gr. silurica in the section. The numbers of specimens from bed No. 35 onward are smaller and diversity is just slightly decreased (cf. Fig. 2).

However, the prominent character in the conodont faunas is sudden decrease in size of specimens that took place in the bed No. 28, where the last Kockelella specimens occur. Conodonts with diminished elements then occur in all samples onward. Calner (2005) mentioned the "low-diversity disaster faunas" with "lilliput effect" on Gotland reflecting the incoming Lau Event (on Fig. 2 this interval is marked as pre-Lau Event faunas). Obviously, the visible change in the conodont faunas is not as drastic as observed on Gotland, also stepwise extinction as on Gotland cannot be proved to such an extent in the shallow sections of the Prague Basin. This can be interpreted by the absence of sediments caused either by truncation or sedimentary starvation in extremely shallow environment. Possibility about missing sedimentary records at this level has been already mentioned (Manda 2003, Lehnert et al. 2007a).

The conodont data indicate that the missing part can be relatively large. The strata from the bed No. 34 may already correspond to the upper part of the Lau Event which can thus be drastically reduced in the former Řeporyje volcanic elevation (i.e. the Požáry and Mušlovka sections). Large gaps in sedimentary record related to the Lau Event have been documented by Barrick et al. (2010) from Laurentia where P. siluricus is immediatelly followed by $O z$.? snajdri. But in contrast to the shallowing in this area and on Gotland, the strata in southern Laurentia are absent due to starvation in deep offshore setting.

The values in $\delta^{13} \mathrm{C}$ record (Lehnert et al. 2007a) start to increase slightly from bed No. 34 in the Požáry section, and at corresponding level in the Mušlovka Quarry, where decrease considerably back to background values before FAD of Oz.? snajdri two meters higher. As mentioned above, the range of $P$. siluricus recorded in these sections is most probably limited only to its lower part, whereas large upper part of the $P$. siluricus range (i.e., the range without Kockelella) is missing. Jeppsson et al. (2006) showed the Lau Event is relatively short-lived, but the correlation of conodonts and carbon isotope record related to the Event indicates that the corresponding time equivalent in strata preserved in this part of the Prague Basin is much shorter. The strata corresponding to the proper Lau Event can be expected approximately above $N$. kozlowskii graptolite Zone that is only indirectly correlated with beds Nos. 33 and 34 in the Požáry section. 


\section{Summary}

A moderate change in diverse conodont faunas of the siluricus Zone started in the faunas coeval to $N$. kozlowskii and the major change took place above the kozlowskii Event that coincides with the recovery of macrofauna in the $P$. latilobus Zone ( $c f$. Manda \& Kř́íz 2006). The correlation between graptolites and conodonts is, however, limited by facies constraints and done only indirectly. The element frequency and observed diversity basically largely depend on changing facies due to abrupt local fluctuation in depth in tectonically active Prague Basin with associated volcanic activity. The global change in conodont faunas corresponding to the Lau Event in the shallower environment of the former Reporyje volcanic elevation is only partly documented by a short interval that corresponds to the part of the Icriodontid Zone on Gotland; it characterizes the upper part of the Lau Event.

The lower part of the Lau Event in Bohemia is missing. Accordingly, the last occurrences of P. siluricus were documented still below the CIE that approximately coincide with the graptolite Kozlowskii extinction Event elsewhere. This incompleteness in record is caused by sedimentary starvation in shallow environment on volcanic elevation. Gaps in sedimentary record of various scales corresponding to the Lau Event documented in many parts of the world were caused by starvation in both shallow and deep-water settings. This illustrates that correlation of global eustatic oscillations and faunal extinctions are often largely obscured by local fluctuations in depth in different environments with varied tectonic stability. The intensity of the Lau Event in Bohemia was rather weak in comparison to Gotland or Australia. These differences may be also caused by different impact of the Event on faunal exctinction in different environments and palaeolatitudes.

\section{Acknowledgments}

The paper was developed with the support of the Czech Science Foundation (project No. 205/09/0703 - Late Silurian integrated stratigraphy... and of the Institute of Geology AS CR, v.v.i. (Institutional project: AV0Z30130516). The authors thank to handling editor for valuable comments and for careful reviews to Carlo Corradini and Michael Murphy that considerably improved the manuscript. We also thank to P. Lisý who helped with the plate preparation, J. Bressler and V. Sedláček for heavy liquid separation, Z. Korbelová for SEM images. Our thanks are also expressed to Hans Peter Schönlaub, Irene Zorn and Rouben Surenian from the Geologische Bundesanstalt Wien for access to the conodont collection for study. Štěpán Manda and Petr Štorch are acknowledged for valuable discussions about the Kozlowskii Event in Bohemia, graptolite stratigraphy and local sedimentology.

\section{References}

Barca, S., Corradini, C., Ferretti, A., Olivieri, R. \& SERPAGLI, E. 1995. Conodont biostratigraphy of the "Ockerkalk" (Silurian) from southeastern Sardinia. Rivista Italiana di Paleontologia e Stratigrafia 100(4), 459-476.

BARNETT, S.G. 1972. The evolution of Spathognathodus remscheidensis in New York, New Jersey, Nevada, and Czechoslovakia. Journal of Paleontology 46, 900-917.

BARRICK, J.E. \& KLAPPER, G. 1976. Multielement Silurian (late Llandoverian-Wenlockian) conodonts of the Clarita Formation, Arbuckle Mountains, Oklahoma, and phylogeny of Kockelella. Geologica et Palaeontologica 10, 59-100.

Barrick, J.E, KlefFner, M.A., Gibson, M.A, PeAvey, F.N. \& KARLSSON, H.R. 2010. In press. The mid-Ludfordian Lau Event and Carbon Isotope Excursion (Ludlow, Silurian) in southern Laurentia - Preliminary Results. Bollettino della Società Paleontologica Italiana 49.

Bischoff, G.C.O. \& Sannemann, D. 1958. Unterdevonische Conodonten aus dem Frankenwald. Notizblatt des Hessischen Landesamtes für Bodenforschung 86, 87-110.

BOUČEK, B. 1937. La stratigraphie du Silurien dans la vallé Daleje prés de Prague et dans son voisinage immédiat. Bulletin international de l'Académie des Sciences de Bohême 46, $160-166$.

Branson, E.B. \& Mehl, M.G. 1933. Conodont Studies. University of Missouri Studies 8 (1-4), 1-343.

CALNER, M. 2005. A Late Silurian extinction event and anachronistic period. Geology 33, 305-308. DOI 10.1130/G21185.1

CALNER, M. 2008. Silurian global events - at the tipping point of climate change, 21-57. In ElEWA, A.M.T. (ed.) Mass Extinction. Springer, Heidelberg.

CARLS, P. \& SLAVÍK, L. 2005. Upgrading of magnetic susceptibility of conodont sample residues before magnetic separation. Lethaia 38, 171-172. DOI 10.1080/00241160510013213

Carls, P., Slavík, L. \& Valenzuela-Ríos, J.I. 2005. A new Ludlow (late Silurian) Spathognathodontidae (Conodonta) from Bohemia with incipient alternating denticulation. Neues Jahrbuch für Geologie und Paläontologie Monatshefte 9, 547-565.

CARls, P., Slavík, L. \& VAlenZuela-Ríos, J.I. 2007. Revision of conodont biostratigraphy across the Silurian-Devonian boundary. Bulletin of Geosciences 82(2), 145-164.

DOI 10.3140/bull.geosci.2007.02.145

CHLUPÁČ, I. 1953. Stratigraphical investigation of the border strata of the Silurian and the Devonian in Central Bohemia. Sborník Ústředního ústavu geologického, Oddíl geologický 20, 277-347.

CHLUPÁČ, I. 1957. Facial development and biostratigraphy of the Lower Devonian of Central Bohemia. Sborník Ústředního ústavu geologického, Oddíl geologický 23, 369-485.

ChlupÁč, I., Hladil, J. \& LuKeš, P. 1986. Field Conference of the ISDS Barrandian-Moravian Karst. A Field Trip Guide Book. 61 pp. Central Geological Survey, Praha.

ChlupÁč, I., Jaeger, H. \& Zikmundová, J. 1972. The Silurian-Devonian boundary in the Barrandian. Bulletin of Canadian Petroleum Geologists 20, 104-174. 
ChluPÁČ, I., KŘİŽ, J. \& SchÖNlaub, H.P. 1980. Field Trip E. Silurian and Devonian conodonts of the Barrandian, 147-180. In SchöNlaub, H.P. (ed.) Second European Conodont Symposium ECOS II. Guidebook - Abstracts. Abhandlungen den Geologischen Bundesanstalt 35.

Corradini, C. \& SERPAgli, E. 1999. A Silurian conodont biozonation from late Llandowery to end Pridoli in Sardinia (Italy), 255-273. In Serpagli, E. (ed.) Studies on Conodonts. Proceedings of the Seventh European Conodont Symposium. Bollettino della Società Paleontologica Italiana 37.

Corradini, C. 2007. The conodont genus Pseudooneotodus Drygnat from the Silurian and Lower Devonian of Sardinia and the Carnic Alps (Italy). Bollettino della Società Paleontologica Italiana 46, 139-148.

Corradini, C., Ferretti, A. \& Štorch, P. eds 2009. The Silurian of Sardinia. Rendiconti della Società Paleontologica Italiana 3(1), 1-170.

Corradini, C., Olivieri, R. \& Serpagli, E. 1995. Possible relationships between anomalous conodonts and Silurian oceanic episodes. Neues Jahrbuch für Geologie und Paläontologie Monatshefte 12, 737-746.

JAHN, J.J. 1902. Geologische Exkursionen im älteren Paläozoikum Mittelböhmens. Verhandlungen der Kaiserlich-königlichen Geologischen Reichsanstalt, 1-44.

JEPPSSON, L. 1969. Notes on some Upper Silurian multielement conodonts. GFF 91, 12-24.

JEPPSSON, L. 1972. Some Silurian conodont apparatuses and possible conodont dimorphism. Geologica et Palaeontologica 6, $51-68$.

JEPPSSON, L. 1974. Aspects of Late Silurian conodonts. Fossils and Strata 6, 1-54.

JEPPSSON, L. 1983. Silurian conodont faunas from Gotland. Fossils and Strata 15, 121-144.

JEPPSSON, L. 1984. Sudden appearances of Silurian conodont lineages; provincialism or special biofacies? 103-112. In CLARK, D.L. (ed.) Conodont Biofacies and Provincialism. Geological Society of America Special Paper 196.

JEPPSSON, L. 1990. An oceanic model for lithological and faunal changes tested on the Silurian record. Journal of the Geological Society London 147, 663-674. DOI 10.1144/gsjgs.147.4.0663

JEPPSSON, L. 1998. Silurian oceanic events. Summary of general characteristics, 239-257. In LANDING, E. \& JoHnson, M.E. (eds) Silurian cycles: Linkages of dynamic stratigraphy with atmospheric, oceanic and tectonic changes. New York State Museum Bulletin 491.

JEPPSSON, L. 2005. Conodont-based revisions of the Late Ludfordian on Gotland, Sweden. GFF 127, 273-282.

JEPPSSON, L. \& ALDRIDGE, R.J. 2000. Ludlow (late Silurian) oceanic episodes and events. Journal of the Geological Society London 157, 1137-1148. DOI 10.1144/jgs.157.6.1137

JePpsson, L., ERIKSSON, M.E. \& CALNER, M. 2006. A latest Llandovery to latest Ludlow high-resolution biostratigraphy based on the Silurian of Gotland - a summary. GFF 128, $109-114$.

Jeppsson, L., Talent, J.A., Mawson, R., Simpson, A.J., AN-
Drew, A.S., Calner, M., Whitford, D.J., Trotter, J.A., SANDSTRÖM, O. \& CALDON, H.J. 2007. High-resolution Late Silurian correlations between Gotland, Sweden, and the Broken River region, NE Australia: Lithologies, conodonts, and isotopes. Palaeogeography, Palaeoclimatology, Palaeoecology 245, 115-137. DOI 10.1016/j.palaeo.2006.02.032

JoHnson, M.E. 2006. Relationship of Silurian sea-level fluctuations to oceanic episodes and events. GFF 128, 115-121.

KlAPPER, G. \& MuRPhy, M.A. 1974. Silurian-Lower Devonian conodont sequences in the Roberts Mountains Formation of central Nevada. University of California Publications in Geological Sciences 111, 1-62.

KLAPPER, G. \& PhILIP, G.M. 1971. Devonian conodont apparatuses and their vicarious skeletal elements. Lethaia 4, 429-452. DOI 10.1111/j.1502-3931.1971.tb01865.x

KLEFFNER, M.A. 1989. A conodont based chronostratigraphy. Bulletin of the Geological Society of America 101, 904-912. DOI 10.1130/0016-7606(1989)101<0904:ACBSC>2.3.CO;2

KLEFFNER, M.A. 1995. A conodont- and graptolite-based Silurian chronostratigraphy. Graphic Correlation, SEPM Special Publication 53, 159-175.

Koptíková, L., BÁBeK, O., Hladil, J., Kalvoda, J. \& Slavík, L. 2010a. Stratigraphic significance and resolution of spectral reflectance logs in Lower Devonian carbonates of the Barrandian area, Czech Republic; a correlation with magnetic susceptibility and gamma-ray logs. Sedimentary Geology 225, 83-98. DOI 10.1016/j.sedgeo.2010.01.004

KoptíkovÁ, L., Hladil, J., Slavík, L., BÁBek, O. \& ČEJChan, P. 2010b. Fine-grained non-carbonate particulates embedded in neritic to pelagic limestones (Lochkovian to Emsian, Prague Synform, Czech Republic): Composition, provenance and links to magnetic susceptibility and gamma-ray logs. Geologica Belgica 13/4, 407-430.

KoREN, T.N. 1993. Main event levels in the evolution of the Ludlow graptolites. Geological Correlation 1, 44-52.

KŘíž, J. 1991. The Silurian of the Prague Basin (Bohemia) - tectonic, eustatic and volcanic controls on facies and faunal development, 179-203. In BASSET, M.G., LANE, P.D. \& EDWARDS, D. (eds) The Murchison Symposium. Proceedings of an international conference on The Silurian System. Special Papers in Palaeontology 44, 1-397.

KŘ́ǐž, J. 1992. Silurian field excursions: Prague Basin (Barrandian) Bohemia. National Museum of Wales, Geological Series $13,1-111$.

Kř́ǐ, J. 1998. Recurrent Silurian-Lowest Devonian cephalopod limestones of Gondwanan Europe and Perunica, 183-198. In LAnding, E. \& Johnson, M.E. (eds) Silurian Cycles: Linkages of Dynamic Stratigraphy with Atmosphaeric, Oceanic, and Tectonic Changes (James Hall Centennial Volume). New York State Museum Bulletin 491.

KŘíž, J. 1999. Geologické památky Prahy. 278 pp. Český geologický ústav, Praha.

KŘíž, J., JAeGer, H., PARIS, F. \& SchÖNLAUb, H.P. 1986. Přídolí - the fourth subdivision of the Silurian. Jahrbuch den Geologischen Bundesanstalt 129, 291-360.

KŘiž, J., JAeger, H., \& SchÖNlaub, H. P. 1981. The Přídolí Series as the fourth series of the Silurian System. A submission to 
the Subcommission on Silurian Stratigraphy, International Commission on Stratigraphy, Subcommission on Silurian Stratigraphy, May 1981, 1-41.

Lehnert, O., ERIKSSON, M.J., CAlner, M., JoAChimsky, M. \& BugGisch, W. 2007b. Concurrent sedimentary and isotopic indications for global climatic cooling in the Late Silurian. Acta Palaeontologica Sinica 46, 249-255.

Lehnert, O., FrýdA, J., Buggisch, W. \& Manda, Š. 2003. A first report of the Ludlovian Lau event from the Prague Basin (Barrandian, Czech Republic), 139-144. In ORTEGA, G. \& ACEÑolazA, G.F. (eds) Proceedings of the $7^{\text {th }}$ International Graptolite Conference and Field Meeting of the International Subcommission on Silurianon Silurian Stratigraphy. Serie Correlación Geológica 18. Instituto Superior de Correlación Geológica (INSUGEO).

Lehnert, O., Fr ÝdA, J., Buggisch, W., MunNeCKe, A., NÜTZEL, A., KŘ́ľ̌, J. \& MANDA, Š. 2007a. $\delta^{13} \mathrm{C}$ records across the late Silurian Lau Event: new data from middle paleolatitudes of northern peri-Gondwana. Palaeogeography, Palaeoclimatology, Palaeoecology 245, 227-244. DOI 10.1016/j.palaeo.2006.02.022

LinK, A.G. \& DRUCE, E.C. 1972. Ludlovian and Gedinnian conodont stratigraphy of the Yass Basin, New South Wales. Geology and Geophysics Bulletin 134, 1-136.

MANDA, Š. 2003. Vývoj a společenstva silurských a ranně devonských hlavonožcových vápenců (pražská pánev, Čechy). 114 pp. Unpublished Diploma thesis, MS Př́rodovědecká fakulta, Universita Karlova, Praha.

MANDA, Š. 2008. Palaeoecology and palaeogeographic relations of the Silurian phragmoceratids (Nautiloidea, Cephalopoda) of the Prague Basin (Bohemia). Bulletin of Geosciences 83, 39-62. DOl 10.3140/bull.geosci.2008.01.039

MANDA, Š. \& KŘíž, J. 2006. Environmental and biotic changes of the subtropical isolated carbonate platforms during Kozlowskii and Lau events (Prague Basin, Silurian, Ludlow). GFF $128,161-168$.

Mehrtens, C.J. \& BARnetT, S.G. 1976. Conodont subspecies from the Upper Silurian-Lower Devonian of Czechoslovakia. Micropaleontology 22, 491-500. DOI 10.2307/1485177

Melchin, J.M., Koren, T.N. \& ŠTORCh, P. 1998. Global Diversity and survivorship patterns of Silurian Graptoloids. New York State Museum Bulletin 491, 165-181.

Munnecke, A., Samtleben, C. \& Bickert, T. 2003. The Ireviken Event in the lower Silurian of Gotland, Sweden - relation to similar Palaeozoic and Proterozoic events. Palaeogeography, Palaeoclimatology, Palaeoecology 195, 99-124. DOI 10.1016/S0031-0182(03)00304-3

MurPhy, M.A., Valenzuela-Ríos, J.I. \& CARls, P. 2004. On Classification of Pridoli (Silurian)-Lochkovian (Devonian) Spathognathodontidae (Conodonts). University of California, Riverside Campus Museum Contribution 6, 1-25.

Prokop, F. 1951. Soupis lomů okres Praha-město a Praha venkov-sever. Soupis lomů ČSR 42, 1-188.

RexroAd, C.B. \& CRAiG, W.W. 1971. Restudy of conodonts from the Bainbridge Formation (Silurian) at Lithium, Missouri. Journal of Paleontology 45, 684-703.
RHOdes, F.H.T. 1953. Some British Lower Palaeozoic conodont faunas. Philosophical Transactions of the Royal Society of London, Series B: Biological Sciences 237, 261-328.

DOI 10.1098/rstb.1953.0005

SerPAGLi, E. \& CoRradini, C. 1998. New taxa of Kockelella (Conodonta) from Late Wenlock-Ludlow (Silurian) of Sardinia, 79-83. In Serpagli, E. (ed.) Sardinia Guide-book, ECOS VII: Giornale di Geologia 60, Special Issue.

SERPAGLi, E. \& CoRRADINI, C. 1999. Taxonomy and evolution of Kockelella (Conodonta) from the Silurian of Sardinia (Italy), 275-298. In Serpagli, E. (ed.) Studies on Conodonts. Proceedings of the Seventh European Conodont Symposium: Bollettino della Società Paleontologica Italiana 37.

Serpagli, E., Corradini, C. \& Ferretti, A. 1998. Conodonts from a Ludlow-Pridoli section near Silius Village, 112-118. In SERPAGLI, E. (ed.) Sardinia Field-trip Guide-book, ECOS VII. Giornale di Geologia 60, Special Issue.

SLAVík, L. 2004a. A new conodont zonation of the Pragian in the Stratotype area (Barrandian, central Bohemia). Newsletters on Stratigraphy 40, 39-71.

DOI $10.1127 / 0078-0421 / 2004 / 0040-0039$

SLAVíK, L. 2004b. The Pragian-Emsian conodont successions of the Barrandian area: search of an alternative to the GSSP polygnathid-based correlation concept. Geobios 37, 454-470. DOI 10.1016/j.geobios.2003.05.002

SLAVíK, L. In press. Lanea carlsi conodont apparatus reconstruction and its significance for subdivision of the Lochkovian. Acta Palaeontologica Polonica.

Slavík, L., Valenzuela-Ríos, J.I., Hladil, J. \& Carls, P. 2007. Early Pragian conodont-based correlations between the Barrandian area and the Spanish Central Pyrenees. Geological Journal 42, 499-512. DOI 10.1002/gj.1087

ŠToRCH, P. 1995a. Upper Silurian (upper Ludlow) graptolites of the $N$. inexpectatus and N. kozlowskii biozones from Kosov Quarry near Beroun (Barrandian area, Bohemia). Bulletin of the Czech Geological Survey 70, 65-89.

ŠTORCH, P. 1995b. Biotic crises and post-crisis recoveries recorded by Silurian planktonic graptolite faunas of the Barrandian area (Czech Republic), 59-70. In ČeJChAN, P., Hladil, J. \& S̆TORCH, P. (eds) Evolution and extinctions. Geolines 3.

SwEET, W.C. \& SCHÖNLAUB, H.P. 1975. Conodonts of the Genus Oulodus Branson \& Mehl, 1933. Geologica et Palaeontologica 9, 41-59.

Talent, J.A., Mawson, R., Andrew, A.S., Hamilton, P.J. \& WhitFORD, D.J. 1993. Middle Palaeozoic extinction events: faunal and isotopic data. Palaeogeography, Palaeoclimatology, Palaeoecology 104, 139-52. DOI 10.1016/0031-0182(93)90126-4

URBANEK, A. 1993. Biotic crises in the history of Upper Silurian graptoloids: A palaeobiological model. Historical Biology 7, 29-50. DOI 10.1080/10292389309380442

VAVRDOVÁ, M. 1989. Early Devonian palynomorphs from the Dvorce-Prokop Limestone (Barrandian region, Czechoslovakia). Bulletin of the Czech Geological Survey 64, 207-219.

VIIRA, V. 1983. Paleontologya drevnego paleozoya pri Baltiky i Podolii, 41-71. In KlaAmann, E. (ed.) Paleontologia drev- 
nego paleozoya Pribaltiki i Podolii. Akademiia nauk Estonskoy SSR, Institut geologii, Talin.

VIIRA, V. 1994. A new Upper Silurian conodont species from Estonia. Proceedings of the Estonian Academy of Sciences, Geology 43, 32-37.

VIIRA, V. 2000. Latest Silurian (Ohesaare Stage) conodonts and the detorta Zone in the Northeastern Baltic. Proceedings of the Estonian Academy of Sciences, Geology 49, 44-62.

WaLliser, O.H. 1957. Conodonten aus dem oberen Gotlandium Deutschlands und der Karnischen Alpen. Notizblatt des hessischen Landesamtes für Bodenforschung 85, 28-52.

WALLISER, O.H. 1964. Conodonten des Silurs. Abhandlungen des
Hessischen Landesamtes für Bodenforschung zu Wiesbaden 41, 1-106.

Walliser, O.H. 1972. Conodont Apparatuses in the Silurian. Geologica et Palaeontologica SB1, 75-80.

WenZel, B. \& JoACHIMSKI, M.M. 1996. Carbon and oxygen isotopic composition of Silurian brachiopods (Gotland/Sweden): Palaeoceanographic implications. Palaeogeography, Palaeoclimatology, Palaeoecology 122, 143-166. DOI 10.1016/0031-0182(95)00094-1

ZIEGLER, W. 1960. Conodonten aus dem Rheinischen Unterdevon (Gedinnium) des Remscheider Sattels (Rheinisches Schiefergebirge). Paläontologische Zeitschrift 34, 169-201. 